\title{
Travel-to-Work and Subjective Well-Being: A Study of UK Dual Career \\ Households
}

\section{Daniel Wheatley ${ }^{1}$}

\begin{abstract}
This article contributes to our understanding of the interaction between travel-to-work, time-use, and subjective well-being among full-time men and women in dual career households. Findings from empirical investigation of the British Household Panel Survey (1993-2009) identify comparable overall time-use (combined commutes, working hours/overtime, housework, and (ill/elderly) care) between genders, however the distributions are distinct. Women report shorter commutes and working hours/overtime, but lengthy housework. Among men lengthier commutes generate dissatisfaction, while the presence of dependent children reduces satisfaction with leisure indicative of the impact of chauffeuring. Women's relationship with travel-to-work appears more complex. Women remain car dependent. Meanwhile, both short and long commutes generate dissatisfaction. Findings indicate short commutes among mothers which reduce satisfaction with leisure time, reflecting multiactivity journeys including the school run. The evidence is indicative of inequality in the household division of labour limiting women's temporal and spatial flexibility and reducing satisfaction with leisure time.
\end{abstract}

Keywords: Dual career households, satisfaction levels, subjective well-being, time-use, travel-to-work.

JEL Classification: J16, J22, J28, J61.

\section{Introduction}

This article contributes to our understanding of the interaction between travel-to-work, timeuse, and subjective well-being among full-time men and women in UK dual career households. Previous research into travel-to-work among dual career households (Wheatley, 2012) and the subjective well-being effects of travel-to-work (De Vos et al, 2013; Ettema, 2010, 2012; Roberts et al, 2011; Stutzer and Frey, 2008) is extended by considering gender

\footnotetext{
${ }^{1}$ Nottingham Business School, Nottingham Trent University.
} 
differences in time-use, travel-to-work and reported satisfaction with hours, job, and amount and use of leisure time. Empirical analysis is conducted using panel data extracted from 17 waves of the British Household Panel Survey, 1993-2009. ${ }^{2}$ Dual career households are defined in this article as men and women in 'managerial', 'professional' or 'associate professional and technical' occupations who report their household as comprising either a: (1) couple with no children; (2) couple with dependent children, or; (3) couple with nondependent children. ${ }^{3}$ These households provide an interesting case as both partners within these households pursue careers in highly skilled occupations which require high levels of commitment (Hardill, 2002; Philp and Wheatley, 2011). These households differ from 'dual earner households' which refers more broadly to households where both partners are engaged in paid work. Empirical research has indicated that managers and professionals continue to work the longest hours of all occupation groups in the UK (Philp and Wheatley, 2011). Fulltime members of dual career households are considered in this article as this implies that a significant portion of their time is devoted to work and necessary work-related activity (i.e. commuting). Moreover, since both partners are full-time career workers the distribution of other elements of time-use — travel-to-work, housework, care — becomes especially relevant as time is particularly constrained.

Travel-to-work routines and the household division of labour may have important impacts in respect to the subjective well-being — referring to self-assessment of an individual's overall well-being (Diener et al, 1999) — of men and women pursuing full-time careers. Subjective

\footnotetext{
${ }^{2}$ The data (and tabulations) used in this (publication) were made available through the ESDS Data Archive. The data were originally collected by the ESDS Research Centre on Micro-Social Change at the University of Essex (now incorporated within the Institute for Social and Economic Research). Neither the original collectors of the data, nor the Archive, bear any responsibility for the analyses or interpretations presented here.

${ }^{3}$ These responses are contained within the BHPS derived variable 'household type' (HHTYPE).
} 
well-being has been the focus of an expanding range of research in psychology, economics, and the broader social sciences (see Kahnemen et al, 2004; Frey and Stutzer, 2002). The focus of the extant literature has been increasing understanding of: (1) what individuals value, and; (2) the factors affecting well-being including links with life satisfaction and happiness (see Diener et al, 1999; Dolan et al, 2008). A stated preference measure, subjective wellbeing is usually derived from survey questions of the form 'All things considered, how satisfied are you with your job as a whole these days', where responses are provided on an ordered Likert scale following the seven 'delighted to terrible' categories outlined by Andrews and Withey (1976). This article aims to contribute to understanding of the interaction between travel-to-work and subjective well-being by considering the case of fulltime men and women in highly skilled occupations. Research is evident of women, in most cases, continuing to experience shorter commutes than men (Hjorthol and Vågane, 2014, 82) effectively limiting their access to labour markets (Frändberg and Vilhelmson, 2011). Household constraints, including the provision of care, result in reduced temporal and spatial flexibility among women, the latter potentially resulting in spatial entrapment (Hanson and Pratt, 1995; Wheatley, 2013). This may have severe career implications for women, especially as employers increasingly demand high levels of flexibility from their workforce (Wheatley, 2012). This article thus attempts to answer the following two research questions:

(1) Are distinctions evident in time-use and travel-to-work between men and women in UK dual career households?

(2) What implications do travel-to-work and the household division of labour have in respect to subjective well-being?

\section{Travel-to-work, household labour and subjective well-being}


Gendered patterns in travel-to-work among dual career households, and the complex time-use found among managers and professionals, should be considered in context to the changing policy environment in the UK. The European Working Time Directive (EWTD) (Council Directive 93/104/EC), passed in November 1993, after being initially refused implementation in the UK was introduced as the Working Time Regulations (WTR) in 1998. It imposes a maximum working week of 48 hours (averaged over 17 weeks) and annual paid leave of at least four weeks, to protect the health and safety of employees. However, in contrast to other European economies the WTR included, from inception, a voluntary opt-out for employees allowing their working hours to exceed the 48 hour limit (BIS, 2011). Further policy has since been implemented in the UK in an attempt to increase the flexibility of paid work. The 2003 Flexible Working Regulations (FWR), extended in 2007, 2009 and 2014, offer workers a range of leave options and the legal right to request a flexible working arrangement albeit these requests can be rejected by employers on grounds of 'business need' (see Deakin and Morris, 2012, 750-2). Concerns continue to surround gaps between the aims and implementation of policy (Wheatley, 2012), however, raising questions regarding the relative impact with respect to realised patterns of time-use including travel-to-work.

\section{Travel-to-work}

In households where individuals work in managerial and professional occupations difficulties are encountered in combining complex patterns of time-use including the commute. The commute acts as a bridge between home and work. It is considered as a "fluid experience equally blended into home life and workplace and points in between” (Basmajian, 2010, 77). The commute varies in distance and complexity throughout an individual's life, including at certain stages activities such as the 'school run'. It is a product of past experience, present routines, and gender norms, and is considered both 'productive' and a 'waste of time' 
(Basmajian, 2010, 76). In many post-industrial economies, including the UK and US, the car remains the dominant method of transport to work as it continues to be perceived the most flexible and convenient (Eriksson et al, 2013; Anable and Gatersleben, 2005). Specific difficulties are encountered by dual career households with respect travel-to-work and residential location. Indeed, it has been suggested that residential location choices can affect well-being through impacts on travel (De Vos et al, 2013). Households may locate close to transport hubs or nodes (Kloosterman and Musterd, 2001, 625). However, this may necessitate lengthier journeys. Long distance weekly commuting strategies are, alternatively, adopted to avoid migration (Sandow and Westin, 2010). Commutes, though, for the majority of workers remain in the form of frequent, often daily, journeys over relatively short distances (Green and Owen, 2006). Partners unable to find two jobs in a preferred locale will compromise. Where compromise is present, though, it is often greater on the part of women (Green, 2004, 636). Research from the Netherlands identified that in households where both partners engage in full-time work it is more likely both will exhibit comparable commuting patterns, potentially evident of more egalitarian attitudes towards task division between partners (de Meester and van Ham, 2009). However, dependent children continue to increase the likelihood of women moving to a part-time working arrangement, and performing a shorter commute. Women remain constrained in their working routines by the presence of children (Philp and Wheatley, 2011). Moreover, gender norms continue to limit women’s spatial mobility, even among highly skilled individuals, resulting in both temporal and spatial constraint (see Wheatley, 2013).

There has been significant debate regarding whether household responsibilities, including housework and care, impact travel-to-work among highly skilled working women. In dual career households there may in principle be no lead career, but the implications this has for 
gender norms, travel-to-work routines, and the household division of labour remain unclear. The economic lives of men and women have converged in the past 50 years, however important divisions persist within the household (Lundberg and Pollak, 2007, 6-7). Moreover, convergence between men and women may not have been realised with respect to commuting. For example, using data from Sweden (1978-2006) it has been shown that men continue to travel longer distances to work, and thus have access to wider labour markets than women (Frändberg and Vilhelmson, 2011).

\section{Temporal and Spatial Mobility}

Evidence is indicative of many women remaining less mobile. Women unable to achieve the level of mobility required by employers may be considered less committed (Sirianni and Negrey, 2000, 72). The presence of dependent children reduces work-time among women, but increases it among men, with potentially important career implications for working mothers (Jacobs and Gerson, 2001, 57). Research is indicative of some improvement in the gendered distribution of household labour (see Sullivan, 2010). Men in some cases do perform a substantial proportion of the chauffeuring of children (Schwanen, 2007). However, many women continue to endure the 'double-shift' (Jones, 2003, 7). This constrains women's travel-to-work in respect to both time and distance (McDowell et al, 2005). Hjorthol and Vågane (2014) consider the case of men and women in Norway. They find that women are limited in regard to labour market opportunities as they tend not to travel as far on average as men (when considering comparable groups). Gender norms are also important in respect to access to a car for travel-to-work. Scheiner and Holz-Rau (2012, 258-9), for example find that while patterns in car use among women are borne out of preference, these preferences are themselves a product of gender norms. Women using a car will do so, often, as they are combining the commute with household activities. This is relevant as other research has 
suggested that access to a car increases temporal flexibility, but that the fixity of certain household tasks may reduce this especially among women (Schwanen et al, 2008, 2119). Hanson and Pratt (1995, 10) described in their seminal US study of Worcester, Massachusetts, that as a result of spatial entrapment many women remain highly dependent on local employment opportunities. Women typically travel short distances to work, as they attempt to manage paid employment alongside household labour, although it is acknowledged that women's travel-to-work patterns are diverse (Hanson and Pratt, 1995, 155; Hjorthol and Vågane, 2014, 82; Frändberg and Vilhelmson, 2011). Women’s spatial mobility is limited as their household responsibilities constrain travel-to-work. This is especially the case among women who are married and those with children (Hanson and Pratt, 1995, 99). Carter and Butler (2008, 12-13), using empirical evidence from the US, identify that dependent children are key drivers in variations in commutes between men and women. Even where children are not present, the household may still limit the mobility of women. Evidence from the UK, reported in Dobbs (2007), identifies gender norms in the distribution of household tasks reduce the available time for travel-to-work, effectively limiting the size of the labour market available to women. Moreover the household division of labour reduces flexibility among women, for example influencing travel-to-work to fit around the ‘school run’ (Dobbs, 2007, 95). Performing the school-run and similar chauffeuring of children have been identified as some of the most temporally and spatially fixed activities second only to sleep and personal care (Schwanen et al, 2008, 2119). Recent mixed methods research focusing on dual career households, provides further reinforcement for the spatial entrapment thesis. Wheatley (2013) uses UK evidence from a 2006 case study of Greater Nottingham and the 2006 Quarterly Labour Force Survey Household Data-Set. This research found evidence of spatial entrapment among career women, and identified school age dependent children as representing a particular constraint, due to provision of care and performing the 'school run'. 


\section{Travel and Subjective Well-being}

Patterns in travel-to-work, which are heavily influenced by the household division of labour, have important implications with respect to subjective well-being. Travel affects well-being in a range of ways (De Vos et al, 2013): through potential travel, activities during travel, participation in activity (work or leisure) enabled by travel, and travel for leisure purposes where travel is the activity which itself acts as a source of utility (Moktharian and Solomon, 2001). Travel-to-work is often perceived as generating dissatisfaction. Research has shown that the commute represents one of the least appreciated activities performed during the day (Kahneman et al, 2004; Wheatley, 2013). Lengthier commutes may reduce 'life' satisfaction, off-setting any benefits individuals receive from 'attractive' residential locations distant from their workplace (Stutzer and Frey, 2008). Other recent research (see Ettema et al, 2012, 21920), though, has identified that commutes may be viewed positively, although relative satisfaction is heavily associated with mode of transport; levels of stress, boredom and other negative feelings, and; exogenous factors (e.g. road maintenance). Satisfaction may be particularly influenced by the extent to which the commute is perceived by the individual to be productive (Basmajian, 2010; Lyons and Urry, 2005), although conflicting evidence is found in this regard (see Ettema et al, 2012). Broader studies have, further, considered the impacts on well-being of transport disadvantage and social exclusion. Delbosc and Currie (2011, 560-1), for example, find that lack of access to transport and/or greater levels of social exclusion (including living in non-urban/rural areas) have detrimental impacts on well-being.

With respect to gendered variations, Roberts et al $(2011,1071)$ use data extracted from the BHPS to consider the psychological effects of commuting on men and women. They find that while commuting has an important detrimental effect on women, this finding is not present 
among men. It is posited that this is a result of women's greater household contribution, including childcare and housework. The presence of dependent children creates added complexity for working women, and may have particularly negative impacts in respect to satisfaction with leisure (Garcia et al, 2007). This is evident of the, at least perceived, constraining effect of these activities. Combined with the lengthy working hours of managerial and professional workers (Philp and Wheatley, 2011), identified in the extant literature as a source of dissatisfaction, the impact of the household division of labour may have particular negative impacts on the subjective well-being of partners in dual career households effectively constraining travel-to-work behaviours.

\section{Method}

This article presents analysis of statistically robust panel data from the BHPS, extending previous research into the interaction between travel-to-work (and other aspects of time-use) and subjective well-being (see Roberts et al, 2011; Ettema et al, 2010; 2012). Data is extracted for full-time working employees aged 16-65. The BHPS began collection in 1992, and was subsumed by the Understanding Society Survey from 2009. It was designed as an annual survey of each adult member (aged 16 years and over) of a nationally representative sample of over 5,000 households (10,000 individuals). Sampled individuals have been successively re-interviewed in subsequent waves, with children interviewed once they reach age 16 (BHPS, 2009). Data on housework has only been collected since 1993, hence the exclusion of wave 1 in the analysis presented. The number of hours spent caring for dependent children is not collected in the BHPS. Instead a measure of who provides childcare within the household is used in the analysis to provide insight into the relative distribution of this task. Meanwhile, although the BHPS provides useful data on numbers of children, this has not been available by age categories e.g. 11-15 for the full sample period. 
The specific impact of school-age children, for example, is not therefore assessed in this article.

Following initial descriptive analysis, ordered probit regression analysis is performed as this provides the most robust method of analysis using discrete dependent variables. The dependent variables comprise reported levels of satisfaction with working hours, job, amount of leisure time, and use of leisure time. These variables are derived from responses to Likert scale questions in the BHPS, where $1=$ completely unsatisfied, $4=$ neither satisfied or unsatisfied, and 7 = completely satisfied. These are regressed against relevant travel-to-work, time-use, demographic, and occupation variables (using UK Standard Occupational Classification Major Groups). It should be acknowledged that men and women working in these broad occupation categories may be in quite different occupations. For example, there may be real differences in the travel-to-work patterns of teachers compared with surgeons. The sample size of the BHPS data, however, prevents statistically robust analysis of occupation levels at lower levels of aggregation. The analysis includes a number of control variables which the extant literature has shown as relevant to satisfaction: age (Blanchflower and Oswald, 2008), gender (Garcia et al, 2007; Philp and Wheatley, 2011), education (Dolan et al, 2008), dependent children (Garcia et al, 2007), and income (Jorgensen et al, 2010). To account for potential time-varying effects in the panel data, time-use variables are considered in three separate time periods, specifically 1993-1998, 1999-2003 and 2004-2009. These reflect policy implemented in the UK relevant to patterns of time-use i.e. WTR in 1998 and FWR in 2003. Moreover, travel-to-work time is categorized into 'short' (up to 20 minutes per journey), ‘mid-length’ (21-59 minutes) and ‘long' (60 or more minutes) providing a nonlinear measure of commuting time. This follows research which has suggested, for example, that individuals are often indifferent towards travelling shorter time-distances of up to 20 
minutes (for a discussion see Redmond and Mokhtarian, 2001), and in addition allows consideration of the specific effects of long (time-distance) commutes. Finally, the analysis includes a series of interaction variables used to test the relative combined impact of travelto-work routines and the presence of dependent children.

\section{Empirical Analysis: British Household Panel Survey}

Initial descriptive analysis of the average distribution of time-use between 1993 and 2009 is presented in Table $1 .{ }^{4}$ In respect to gender differences, employer-related time-use is longer, overall, among men. Full-time working hours, and hours of overtime, have remained consistently lengthier among men in managerial and professional occupations. However, there remain some notable exceptions to these trends, especially if disaggregated by sector. For example, mean hours of overtime reported among public sector professional women are particularly long (see Table 1). They are consistently the longest at between seven and nine hours per week during the sample period. Women's total work-time in these occupations is similar to their male counterparts. Commutes act as an important additional time constraint. This is particular evident among managers where relatively high proportions of both men (19.1\%) and women (18.8\%) report undertaking long commutes (60 or more minutes). However, consistent with Hjorthol and Vågane $(2014,82)$ time spent commuting is notably shorter overall among women: 53\% of women report short commutes (up to 20 minutes), compared with $42.3 \%$ of men. This is driven by shorter commutes among professionals. Women in public sector professional and associate professional occupations, for example,

\footnotetext{
${ }^{4}$ ANOVA tests confirm that the patterns among men and women by occupation group (interaction) observed in annual mean hours in Table $1-$ mean working hours $(\mathrm{F}=2.77$, S.E. $=1.510$, $\mathrm{p}$-value 0.019$)$, overtime $(\mathrm{F}=$ 5.33, S. E. $=1.367$, p-value 0.000$)$, commutes $(\mathrm{F}=2.50$, S.E. $=0.611$, p-value 0.032$)$, housework $(\mathrm{F}=4.21$, S.E. $=1.125$, p-value 0.001), and care $(F=4.41$, S.E. $=0.825$, p-value 0.001$)$ - are statistically significant.
} 
spend on average 4 hours and 4.1 hours per week respectively commuting (see Table 1). Moreover, just $7.8 \%$ and $9.7 \%$ of these women report long journeys. Even in this highly skilled occupation group where women report comparable work-time to men, their commutes remain significantly shorter. In addition, women working in public sector professions report the greatest car dependency: 88.3\% report travelling by car (van or motorcycle) on average (average dependency for all career women is 81.0\%). This is substantially higher than among men (78.5\%), although it is worth noting that men in managerial occupations do report high levels of car dependency (85.1\%) and lengthy commutes. The driver of the travel-to-work patterns of women may not though be work-time, but instead household factors.

Table 1: Weekly time-use (in hours) among dual career households, BHPS 1993-2009

\begin{tabular}{|c|c|c|c|c|c|c|c|c|}
\hline & Occupation & Sector & Hours & Overtime & Commute & Housework & $\begin{array}{l}\text { Care (ill or } \\
\text { elderly) }\end{array}$ & $n$ \\
\hline \multirow[t]{9}{*}{ Men } & \multirow{3}{*}{$\begin{array}{l}\text { Managers and senior } \\
\text { officials }\end{array}$} & Private & 42.1 & 7.3 & 5.4 & 4.5 & 0.5 & 163 \\
\hline & & Public & 40.3 & 5.5 & 6.0 & 5.7 & 1.8 & 33 \\
\hline & & Overall & 41.8 & 7.0 & 5.5 & 4.7 & 0.7 & 196 \\
\hline & \multirow[t]{3}{*}{ Professionals } & Private & 38.7 & 5.6 & 5.8 & 4.5 & 0.4 & 80 \\
\hline & & Public & 39.5 & 6.5 & 4.7 & 6.4 & 0.8 & 79 \\
\hline & & Overall & 39.1 & 6.0 & 5.3 & 5.4 & 0.6 & 159 \\
\hline & \multirow{3}{*}{$\begin{array}{l}\text { Associate } \\
\text { professional and } \\
\text { technical }\end{array}$} & Private & 38.9 & 4.1 & 5.5 & 4.6 & 0.5 & 93 \\
\hline & & Public & 38.1 & 2.8 & 5.1 & 6.2 & 0.8 & 73 \\
\hline & & Overall & 38.5 & 3.5 & 5.3 & 5.3 & 0.6 & 166 \\
\hline \multirow[t]{9}{*}{ Women } & \multirow{3}{*}{$\begin{array}{l}\text { Managers and senior } \\
\text { officials }\end{array}$} & Private & 39.8 & 5.5 & 5.4 & 9.3 & 0.6 & 88 \\
\hline & & Public & 36.5 & 4.1 & 5.0 & 11.1 & 0.8 & 38 \\
\hline & & Overall & 38.8 & 5.1 & 5.3 & 9.8 & 0.7 & 126 \\
\hline & \multirow[t]{3}{*}{ Professionals } & Private & 37.7 & 5.7 & 5.1 & 8.1 & 0.3 & 52 \\
\hline & & Public & 37.6 & 8.5 & 4.1 & 9.9 & 1.2 & 154 \\
\hline & & Overall & 37.6 & 7.8 & 4.4 & 9.4 & 1.0 & 206 \\
\hline & \multirow{3}{*}{$\begin{array}{l}\text { Associate } \\
\text { professional and } \\
\text { technical }\end{array}$} & Private & 37.3 & 3.9 & 4.9 & 9.5 & 1.0 & 74 \\
\hline & & Public & 36.9 & 2.8 & 4.2 & 10.6 & 0.9 & 128 \\
\hline & & Overall & 37.0 & 3.2 & 4.5 & 10.2 & 0.9 & 202 \\
\hline
\end{tabular}

Source: British Household Panel Survey, 1993-2009.

Notes: Data is for full-time employees aged 16-65. Figures (including n values) are averages taken over sample period (17 observations). 
Perhaps the greatest distinction between men and women, even among careerists, remains the stark variations in housework. Hours of housework average 9.8 hours per week among fulltime career women, almost double that of men (5.2 hours). Moreover, housework has remained a female preserve throughout the 17 year sample period, suggesting a less than egalitarian household division of labour. Meanwhile, the reported hours of (ill/elderly) care among women are also longer, with male public sector managers offering the only exception (see Table 1). Lengthy household time is particularly severe for women professionals (and associate professionals). On average, between 1993-2009 women working full-time in public sector professional occupations, although reporting shorter working hours (37.6 hours per week) than their male counterparts (39.5 hours per week), report lengthy hours of overtime (8.5 hours), housework (9.9 hours), and some of the longest average reported hours of ill/elderly care (1.2 hours). This reported time-use does not include the additional burden of hours spent caring for dependent children which often remains the preserve of women (Garcia et al, 2007). The BHPS data confirms this trend is present among dual career households. Responses to the question, 'Who is mainly responsible for looking after the child(ren)?', continue to reflect significant gender divisions with $56.7 \%$ of women on average reporting they are the main care provider, compared with just $3.8 \%$ of men (remaining couples report that caring is shared between partners). This is also important as childcare is associated with lower levels of satisfaction (Garcia et al, 2007). The greater household contribution is also likely to leak into other activities including travel, through multi-activity journeys (including shopping and the 'school run'). The patterns present in respect to time-use are indicative of important distinctions between men and women. The shorter commutes and lengthier hours of housework reported may have important implications in respect to women's mobility and subjective well-being. 
The BHPS includes a number of questions which explicitly focus on satisfaction. Responses to these questions disaggregated by commuting time are summarized in Table $2 .{ }^{5}$ During the sample period satisfaction with hours, on average, is lowest among full-time women professionals (62.6\%). This corresponds closely with the extensive time-use in this occupation group summarized in Table 1 . With reference to the commute, satisfaction with working hours is on average lower among men reporting long commutes. However, this finding is not as prevalent among women. In fact women reporting long commutes (60 or more minutes) report greater satisfaction with hours than those with short commutes. This may be evident of the greater flexibility enjoyed by those with fewer household responsibilities (and perhaps no dependent children). Satisfaction with job overall is actually greatest among professional men (74.3\%) and women (74.5\%), and women managers (75.4\%). In the latter case this could be at least in part due to the shorter work-time associated with this occupation group. However, for professionals this is indicative of workers gaining satisfaction from their employment in spite of lengthy working hours which themselves may create dissatisfaction, perhaps evident of the role of job quality in influencing satisfaction (Brown et al, 2012). No clear correlation, however, is found between satisfaction with job and commuting time (evident in the lack of statistical significance in the variations reported).

Table 2: Satisfaction levels, BHPS 1993-2009

\begin{tabular}{cc|ccc|c}
\hline Occupation & \multicolumn{4}{|c}{ Satisfaction with ... (\%) } \\
& $\begin{array}{c}\text { Commute } \\
\text { (minutes) }\end{array}$ & Hours & Work & Leisure & Leisure \\
time & use & n \\
\hline
\end{tabular}

\footnotetext{
${ }^{5}$ Results in Table 2 are summarized for all those responding positively i.e. 5-7 on the likert scale. ANOVA tests confirm that the patterns among men and women by occupation (interaction) observed in satisfaction with hours $(\mathrm{F}=6.573$, $\mathrm{p}$-value 0.002$)$ and amount of leisure time $(\mathrm{F}=2.958$, p-value 0.054$)$ are statistically significant. Satisfaction with job $(\mathrm{F}=0.630, \mathrm{p}$-value 0.534$)$ and use of leisure time $(\mathrm{F}=0.635$, p-value 0.531$)$ are statistically insignificant, however, casting some doubt over the reliability of the differences observed.
} 


\begin{tabular}{|c|c|c|c|c|c|c|c|}
\hline \multirow[t]{9}{*}{ Men } & \multirow[t]{3}{*}{ Managers and senior officials } & $0-20$ & 65.2 & 76.3 & 49.9 & 64.0 & 84 \\
\hline & & $21-59$ & 68.0 & 72.7 & 46.5 & 61.6 & 75 \\
\hline & & $60+$ & 66.2 & 70.4 & 38.0 & 53.1 & 37 \\
\hline & \multirow[t]{3}{*}{ Professional } & $0-20$ & 73.6 & 76.9 & 56.7 & 66.1 & 65 \\
\hline & & $21-59$ & 69.6 & 73.0 & 47.8 & 64.3 & 72 \\
\hline & & $60+$ & 62.0 & 71.0 & 33.3 & 58.6 & 22 \\
\hline & \multirow[t]{3}{*}{ Associate prof. and technical } & $0-20$ & 75.9 & 70.9 & 55.9 & 63.0 & 71 \\
\hline & & $21-59$ & 71.6 & 67.9 & 51.1 & 61.0 & 68 \\
\hline & & $60+$ & 66.6 & 74.1 & 47.5 & 63.6 & 27 \\
\hline \multirow[t]{9}{*}{ Women } & \multirow[t]{3}{*}{ Managers and senior officials } & $0-20$ & 70.9 & 77.1 & 47.2 & 58.8 & 62 \\
\hline & & $21-59$ & 71.1 & 73.4 & 44.4 & 61.5 & 40 \\
\hline & & $60+$ & 65.1 & 74.4 & 41.0 & 56.9 & 24 \\
\hline & \multirow[t]{3}{*}{ Professionals } & $0-20$ & 62.5 & 73.2 & 43.9 & 56.3 & 108 \\
\hline & & $21-59$ & 60.3 & 75.6 & 45.9 & 60.6 & 82 \\
\hline & & $60+$ & 75.5 & 77.9 & 45.6 & 58.4 & 16 \\
\hline & \multirow[t]{3}{*}{ Associate prof. and technical } & $0-20$ & 75.0 & 73.5 & 48.0 & 60.5 & 114 \\
\hline & & $21-59$ & 73.1 & 74.6 & 53.7 & 63.7 & 69 \\
\hline & & $60+$ & 77.4 & 75.5 & 41.5 & 57.3 & 20 \\
\hline
\end{tabular}

Source: British Household Panel Survey, 1993-2009.

Notes: Data is for full-time employees aged 16-65. Figures (including n values) are averages over sample period (16 observations) excluding 2002 (no satisfaction data collected). Figures for satisfaction with amount and use of leisure time are averages over 12 years only (questions not included in earlier surveys).

The sample size of the BHPS does not permit robust additional disaggregation by private/public sector. 
Overall, dual career households appear more satisfied with their leisure use than they are the amount of leisure time. This reflects the demanding nature of the occupations in which partners in these households work which limits the availability of leisure time, but provides income enabling more desirable consumption of leisure activities. Within this general pattern, though, there are notable distinctions. For example, associate professionals report the greatest satisfaction with amount of leisure (and use among women). This is likely to be a product of the shorter working hours reported by these employees. Meanwhile, long commutes are a source of dissatisfaction with amount and use of leisure among men. In contrast, women professionals reporting short (up to 20 minutes) commutes are relatively less satisfied with the use, and in particular the amount, of leisure time compared with those reporting lengthier travel-to-work. This finding is not present among men. It appears that for women both long and short commutes are a source of dissatisfaction. In respect of the latter, this is evident of the constraining effect of women's greater household contribution (Guillaume and Pochic, 2009; McDowell et al, 2005) and the presence of dependent children (Garcia et al, 2007). Those commuting shorter distances often combine multiple activities with travel-to-work, including the school run (Wheatley, 2013). The constraining effect of these activities, rather than the length of the commute, may therefore be responsible for lower levels of satisfaction among women working closer to home. This finding suggests an inherent gender division in satisfaction with leisure in dual career households. Women in professional occupations, associated with long working hours inclusive of overtime (see Table 1), are relatively satisfied with the nature and routines of their employment. When considering the length of commutes, however, dissatisfaction with leisure is evident. Shorter commutes themselves should not act as a significant source of dissatisfaction. Instead this may be the result of other aspects of time-use and household factors. 


\subsection{Ordered Probit Panel Estimation Results}

In order to best capture the gender differences in satisfaction levels and their determinants separate regression models are performed for full-time men and women. The results of the ordered probit panel models are presented in Table 3 (men) and 4 (women). Firstly, it is important to note that among these occupation groups there are a number of similarities. For example, both working hours and overtime are associated with lower levels of satisfaction with hours and amount and use of leisure time. Consistent with the descriptive findings, these relationships remain present throughout the sample period. In addition the results pertaining to age and age $\mathrm{a}^{2} / 100$ are comparable between genders. Age is non-linear reflecting the additional constraint present during the middle part of individuals' careers. This may, in part, be associated with the presence of dependent children which reduces satisfaction with amount and use of leisure time among both men and women. However, while consistencies are found there are important contrasting results. Income is only significant to satisfaction among men. Financial compunction may be the driver of this response. However, it could also be indicative of a more mercenary approach to life among men. Public sector men are more satisfied with hours, job and amount of leisure time. However, this relationship is not present among career women. Meanwhile, women with higher qualifications report lower levels of satisfaction with hours and job overall (although results for education are mixed across the remaining measures of satisfaction).

Table 3: Ordered Probit Regression Models: Satisfaction among full-time men

\begin{tabular}{ccccc}
\hline & \multicolumn{4}{c}{ Ordered Probit Regression Models (men) } \\
\cline { 2 - 6 } & $\begin{array}{c}\text { Satisfaction } \\
\text { with hours }\end{array}$ & $\begin{array}{c}\text { Satisfaction } \\
\text { with job }\end{array}$ & $\begin{array}{c}\text { Satisfaction } \\
\text { with } \\
\text { amount of } \\
\text { leisure time }\end{array}$ & $\begin{array}{c}\text { Satisfaction } \\
\text { with use of } \\
\text { leisure time }\end{array}$ \\
\hline $\begin{array}{c}\text { Working hours } \\
1993-1998\end{array}$ & $-0.034^{* * *}$ & $0.005^{* * *}$ & $-0.021^{* * *}$ & $-0.007^{* * *}$
\end{tabular}




$\begin{array}{lllll}1999-2003 & -0.035^{* * *} & 0.003^{*} & -0.021^{* * *} & -0.008^{* * *} \\ 2004-2009 & -0.035^{* * *} & 0.004^{*} & -0.022^{* * *} & -0.011^{* * *}\end{array}$

Overtime hours

$\begin{array}{rrrrr}1993-1998 & -0.036 * * * & 0.006 * * & -0.029 * * * & -0.016^{* * *} \\ 1999-2003 & -0.040^{* * *} & 0.002 & -0.028^{* * *} & -0.011^{* * *} \\ 2004-2009 & -0.042^{* * *} & -0.002 & -0.025^{* * *} & -0.014^{* * *}\end{array}$

Housework hours

$\begin{array}{rrrrr}1993-1998 & 0.008 & -0.007 & 0.001 & -0.016^{* *} \\ 1999-2003 & 0.008^{* *} & -0.003 & -0.001 & -0.018^{* * *} \\ 2004-2009 & 0.010^{* * *} & -0.007^{*} & -0.005 & -0.001 \\ \text { derly) hours } & & & & \\ 1993-1998 & 0.010^{* * *} & 0.001 & 0.009 * & 0.003 \\ 1999-2003 & 0.004 & 0.003 & 0.001 & -0.003 \\ 2004-2009 & 0.000 & 0.013^{* * *} & -0.001 & 0.001 \\ & -0.071^{* * *} & -0.084^{* * *} & -0.059 * * * & -0.035^{* * *} \\ & 0.081^{* * *} & 0.102^{* * *} & 0.069 * * * & 0.043^{* * *} \\ & 0.007 & -0.031 & 0.021 & 0.006 \\ & 0.080^{* *} & 0.116^{* * *} & -0.062^{* *} & -0.013^{* *}\end{array}$

Who performs childcare in household?: reference is partner

\begin{tabular}{|c|c|c|c|c|}
\hline Age & $-0.071 * * *$ & $-0.084 * * *$ & $-0.059 * * *$ & $-0.035^{* * *}$ \\
\hline $\mathrm{Age}^{2} / 100$ & $0.081 * * *$ & $0.102 * * *$ & $0.069 * * *$ & $0.043^{* * *}$ \\
\hline Married & 0.007 & -0.031 & 0.021 & 0.006 \\
\hline No. children & $0.080 * *$ & $0.116^{* * *}$ & $-0.062 * *$ & $-0.013^{* *}$ \\
\hline \multicolumn{5}{|c|}{ Who performs childcare in household?: reference is partner } \\
\hline Respondent main carer & -0.081 & 0.001 & -0.184 & -0.022 \\
\hline Both provide care & -0.026 & -0.045 & -0.035 & -0.029 \\
\hline \multicolumn{5}{|c|}{ Education level: reference is no qualifications } \\
\hline Degree & -0.036 & -0.021 & $-0.218 * * *$ & -0.074 \\
\hline A Level & 0.046 & -0.018 & -0.033 & 0.058 \\
\hline GCSE & 0.054 & 0.042 & -0.035 & $0.097 *$ \\
\hline
\end{tabular}

Occupation group: reference is associate professional and technical

$\begin{array}{lrrrr}\text { Managers } & 0.021 & 0.082 * * * & -0.002 & 0.036 \\ \text { Professionals } & 0.034 & 0.035 & 0.007 & 0.034 \\ \text { Private sector } & -0.051^{* *} & -0.055^{* *} & -0.107 * * * & 0.032 \\ \text { Annual income (000s) } & 0.003^{* * *} & 0.004 * * * & 0.001 * * & 0.000\end{array}$

Travel-to-work time (including interactions): reference is $0-20 \mathrm{mins}$ 21-59min.

$\begin{array}{rrrrr}1993-1998 & -0.034 & -0.065 & 0.002 & 0.121^{*} \\ 1999-2003 & -0.056 & 0.003 & -0.059 & 0.096^{*} \\ 2004-2009 & -0.024 & -0.031^{* *} & -0.137^{* * *} & -0.017\end{array}$

21-59min.*no. children 1993-1998

$1999-2003$

$\begin{array}{rr}-0.077^{* *} & 0.013^{* * *} \\ -0.041 & -0.028 \\ -0.060^{* *} & -0.006\end{array}$

$-0.101 * * *$

$-0.123 * *$ 2004-2009

$60+\min$.

$1993-1998$
$1999-2003$
$2004-2009$

$-0.227 * * *$
$-0.183^{* * *}$
$-0.122 * *$

$$
\begin{array}{r}
-0.163^{*} \\
-0.075 \\
-0.157 * * *
\end{array}
$$

$$
-0.054
$$$$
-0.131 * * *
$$$$
-0.003
$$$$
-0.006
$$

60+ min.*no. children

$$
\begin{aligned}
& 1993-1998 \\
& 1999-2003 \\
& 2004-2009
\end{aligned}
$$

$$
\begin{array}{r}
-0.140 * * \\
0.000 \\
-0.028
\end{array}
$$$$
-0.379 * * *
$$$$
-0.052
$$$$
-0.089 *
$$$$
-0.031
$$$$
-0.186 * * *
$$$$
-0.158 *
$$$$
-0.139 * *
$$$$
0.003
$$$$
0.009
$$$$
-0.065
$$$$
0.001
$$

0.013

$-0.026$

Method of transport to work: reference is public (train, bus)

\begin{tabular}{lrrrr} 
Car, van, motorbike & 0.062 & $0.101^{* *}$ & $0.175^{* * *}$ & $0.160^{* * *}$ \\
Car*no. children & -0.009 & -0.054 & $-0.064 \dagger$ & $-0.095^{* *}$ \\
Manual (walk, bicycle) & 0.069 & $0.101 \dagger$ & $0.135^{*}$ & $0.243^{* * *}$ \\
Manual*no. children & -0.074 & $-0.125^{* *}$ & -0.043 & -0.039 \\
\hline
\end{tabular}




\begin{tabular}{|c|c|c|c|c|}
\hline \multicolumn{5}{|l|}{ Model Diagnostics } \\
\hline Pseudo R-squared & 0.036 & 0.009 & 0.029 & 0.016 \\
\hline LR statistic & 1188.458 & 252.038 & 791.504 & 429.900 \\
\hline Prob(LR statistic) & 0.000 & 0.000 & 0.000 & 0.000 \\
\hline Log likelihood & -15735.220 & -13824.860 & -13196.610 & -12832.550 \\
\hline Restr. log likelihood & -16329.450 & -13950.080 & -13592.360 & -13047.500 \\
\hline Avg. log likelihood & -1.574 & -1.383 & -1.677 & -1.631 \\
\hline Panel observations & 9,998 & 9,996 & 7,871 & 7,869 \\
\hline $\begin{array}{l}\text { Source: British house } \\
\text { 1997-2009 (satisfacti } \\
\text { Notes: significance le } \\
\text { respectively. } † \text { denote }\end{array}$ & $\begin{array}{l}\text { el survey, } 1 \text { c } \\
\text { eisure amou } \\
\%, 5 \% \text { and } \\
\text { ient at } 15 \%\end{array}$ & $\begin{array}{l}3-2009 \text { (satis } \\
\text { leisure use) } \\
\% \text { are denote }\end{array}$ & $\begin{array}{l}\text { faction with } \mathrm{h} \\
\mathrm{d} \text { by } * * *, * *\end{array}$ & $\begin{array}{l}\text { s, job), } \\
*\end{array}$ \\
\hline
\end{tabular}


Table 4: Ordered Probit Regression Models: Satisfaction among full-time women

\begin{tabular}{|c|c|c|c|c|}
\hline & \multicolumn{4}{|c|}{ Ordered Probit Regression Models (women) } \\
\hline & $\begin{array}{l}\text { Satisfaction } \\
\text { with hours }\end{array}$ & $\begin{array}{l}\text { Satisfaction } \\
\text { with job }\end{array}$ & $\begin{array}{c}\text { Satisfaction } \\
\text { with } \\
\text { amount of } \\
\text { leisure time }\end{array}$ & $\begin{array}{l}\text { Satisfaction } \\
\text { with use of } \\
\text { leisure time }\end{array}$ \\
\hline \multicolumn{5}{|l|}{ Working hours } \\
\hline 1993-1998 & $-0.035 * * *$ & -0.003 & $-0.027 * * *$ & $-0.008 * * *$ \\
\hline 1999-2003 & $-0.037 * * *$ & $-0.009 * * *$ & $-0.026 * * *$ & $-0.008 * * *$ \\
\hline 2004-2009 & $-0.036 * * *$ & $-0.006^{* * *}$ & $-0.024 * * *$ & $-0.010 * * *$ \\
\hline \multicolumn{5}{|l|}{ Overtime hours } \\
\hline 1993-1998 & $-0.048 * * *$ & $-0.008 * *$ & $-0.028 * * *$ & $-0.013^{* * *}$ \\
\hline 1999-2003 & $-0.054 * * *$ & $-0.010 * * *$ & $-0.030 * * *$ & $-0.014^{* * *}$ \\
\hline 2004-2009 & $-0.041 * * *$ & $-0.008 * * *$ & $-0.023 * * *$ & $-0.013 * * *$ \\
\hline \multicolumn{5}{|l|}{ Housework hours } \\
\hline 1993-1998 & 0.001 & 0.001 & -0.003 & -0.003 \\
\hline 1999-2003 & -0.002 & 0.000 & $-0.006^{*}$ & $-0.008 * *$ \\
\hline 2004-2009 & 0.003 & 0.000 & $-0.006^{* *}$ & -0.001 \\
\hline \multicolumn{5}{|l|}{ Care (ill/elderly) hours } \\
\hline 1993-1998 & $0.009 * *$ & 0.005 & 0.002 & 0.004 \\
\hline 1999-2003 & 0.000 & -0.004 & 0.004 & 0.002 \\
\hline 2004-2009 & -0.001 & -0.003 & $-0.016 * * *$ & $-0.015^{* * *}$ \\
\hline Age & $-0.042 * * *$ & $-0.042 * * *$ & $-0.048 * * *$ & $-0.046^{* * *}$ \\
\hline $\mathrm{Age}^{2} / 100$ & $0.039 * * *$ & $0.049 * * *$ & $0.048 * * *$ & $0.054^{* * *}$ \\
\hline Married & -0.004 & $0.073 * * *$ & 0.034 & 0.015 \\
\hline No. children & 0.012 & -0.014 & $-0.079 * *$ & -0.029 \\
\hline \multicolumn{5}{|c|}{ Who performs childcare in household?: reference is partner } \\
\hline Respondent main carer & $-0.098 * *$ & $-0.073 \dagger$ & $-0.281 * * *$ & $-0.174 * * *$ \\
\hline Both provide care & $-0.111^{* *}$ & -0.036 & $-0.143 * * *$ & $-0.133 * *$ \\
\hline \multicolumn{5}{|c|}{ Education level: reference is no qualifications } \\
\hline Degree & $-0.338 * * *$ & $-0.232 * * *$ & -0.079 & 0.051 \\
\hline A Level & $-0.344 * * *$ & $-0.211 * * *$ & $-0.157 * *$ & -0.086 \\
\hline GCSE & $-0.186^{* * *}$ & -0.087 & 0.018 & 0.015 \\
\hline \multicolumn{5}{|c|}{ Occupation group: reference is associate professional and technical } \\
\hline Managers & 0.027 & $0.088 * * *$ & 0.017 & -0.033 \\
\hline Professionals & $-0.095^{* * *}$ & 0.035 & $-0.069 *$ & -0.057 \\
\hline Private sector & -0.037 & $-0.048 \dagger$ & -0.024 & $0.054 *$ \\
\hline Annual income (000s) & 0.000 & 0.001 & -0.001 & 0.000 \\
\hline \multicolumn{5}{|c|}{$\begin{array}{l}\text { Travel-to-work time (including interactions): reference is 0-20mins } \\
\text { 21-59min. }\end{array}$} \\
\hline 1993-1998 & $-0.187 * * *$ & $-0.206 * * *$ & 0.088 & 0.068 \\
\hline 1999-2003 & 0.002 & 0.006 & 0.059 & 0.061 \\
\hline 2004-2009 & $-0.074 \dagger$ & $-0.094 * *$ & $-0.105 * *$ & -0.046 \\
\hline \multicolumn{5}{|l|}{ 21-59min.*no. children } \\
\hline 1993-1998 & 0.066 & 0.039 & $-0.114^{*}$ & -0.127 \\
\hline 1999-2003 & -0.043 & -0.004 & $-0.197 * * *$ & $-0.164 * * *$ \\
\hline 2004-2009 & 0.037 & -0.037 & -0.010 & 0.024 \\
\hline \multicolumn{5}{|l|}{$60+\min }$. \\
\hline 1993-1998 & -0.098 & -0.136 & $-0.249 *$ & $-0.220 \dagger$ \\
\hline 1999-2003 & $0.222 * * *$ & 0.018 & 0.093 & 0.002 \\
\hline 2004-2009 & -0.101 & $-0.001 \dagger$ & $-0.163 * *$ & -0.097 \\
\hline
\end{tabular}




\begin{tabular}{|c|c|c|c|c|}
\hline \multicolumn{5}{|l|}{$60+$ min. ${ }^{*}$ no. children } \\
\hline 1993-1998 & 0.111 & 0.067 & $-0.257 \dagger$ & -0.076 \\
\hline $1999-2003$ & -0.119 & $0.191 \dagger$ & $-0.358 * * *$ & $-0.192 \dagger$ \\
\hline 2004-2009 & -0.058 & -0.045 & 0.039 & -0.032 \\
\hline \multicolumn{5}{|c|}{ Method of transport to work: reference is public (train, bus) } \\
\hline Car, van, motorbike & 0.046 & $0.105^{* *}$ & -0.063 & 0.071 \\
\hline Car*no. children & 0.050 & $0.108 *$ & -0.002 & $-0.092 *$ \\
\hline Manual (walk, bicycle) & $0.105 \dagger$ & $0.130 *$ & 0.020 & $0.118 \dagger$ \\
\hline Manual*no. children & -0.031 & 0.068 & -0.058 & -0.024 \\
\hline \multicolumn{5}{|l|}{ Model Diagnostics } \\
\hline Pseudo R-squared & 0.047 & 0.009 & 0.030 & 0.018 \\
\hline LR statistic & 1068.276 & 165.921 & 580.733 & 328.951 \\
\hline Prob(LR statistic) & 0.000 & 0.000 & 0.000 & 0.000 \\
\hline Log likelihood & -10711.190 & -9361.785 & -9281.834 & -9134.851 \\
\hline Restr. log likelihood & -11245.330 & -9444.745 & -9572.200 & -9299.326 \\
\hline Avg. log likelihood & -1.565 & -1.367 & -1.693 & -1.667 \\
\hline Panel observations & 6,846 & 6,846 & 5,481 & 5,479 \\
\hline \multicolumn{5}{|c|}{$\begin{array}{l}\text { Source: British household panel survey, } 1993-2009 \text { (satisfaction with hours, job), } \\
1997-2009 \text { (satisfaction with leisure amount, leisure use). } \\
\text { Notes: significance levels of } 1 \%, 5 \% \text { and } 10 \% \text { are denoted by } * * *, * * \text { and * } \\
\text { respectively. } \dagger \text { denotes coefficient at } 15 \% \text { significance. }\end{array}$} \\
\hline
\end{tabular}

Time spent performing housework and (ill/elderly) care appear important to women in respect to both amount and use of leisure time, but with the exception of housework reducing satisfaction with use of leisure time between 1993 and 2003, these associations are not found among men. Interestingly, the negative association with (ill/elderly) care is only present among women between 2004 and 2009. This may reflect changes throughout the life-course for those women in the BHPS sample. The findings pertaining to housework and care are indicative of the impact of the household division of labour on women's time-use, which limits the availability of leisure time. This result is compounded in the negative associations present when considering the impact of caring for dependent children among women who report that they are the main care provider within their household. These women report lower levels of satisfaction with amount of leisure, reflecting their greater household contribution. This finding is again not present among men.

Of specific interest to this article are the results pertaining to travel-to-work. Long commutes (60 or more minutes) are associated with lower levels of satisfaction among men across the 
measures considered and throughout the sample period. This is consistent with the descriptive analysis and provides evidence of the negative associations present with respect to lengthier travel-to-work (Kahneman et al, 2004; Stutzer and Frey, 2008). This is likely to be particularly pronounced among male careerists due to the time constraints associated with long working hours (inclusive of overtime) when combined with extensive commutes. Meanwhile, men undertaking mid-length commutes actually report greater satisfaction with the use of their leisure time (than those performing short commutes), perhaps evident of short commutes only being undertaken by men where significant constraint (either financial or related to household responsibilities) is present. Women's relationship with the commute appears more complex. Overall, women reporting 21-59 minute commutes appear less satisfied with their working hours and job (compared to those with commutes of up to 20 minutes), although it should be noted this finding is not present between 1999 and 2003. However, mid-length commutes do not appear to be a source of dissatisfaction with leisure, overall, among women. Meanwhile, those reporting long commutes are unhappy with the amount of leisure time as would be expected. Perhaps of most significance, though, is the combined impact of the commute and the presence of dependent children. Among mothers, performing both mid-length and long commutes is associated with lesser satisfaction with amount and use of leisure. This finding is not, though, present for fathers reporting long commutes. With respect to time-varying effects, this finding is also not present for men or women in 2004-2009. This could be evidence of the benefits of increased flexibility resulting from the implementation of the Flexible Working Regulations. The findings are indicative of childcare and similar activities impacting, in particular, the availability of leisure for women, but not satisfaction with use of the leisure time that is experienced. This may be evident of a level of separation in the perception of availability and use of leisure time. This extends the descriptive analysis and is indicative of the impact on women of multi-activity commutes 
combining caring tasks including the school run. The commute alone may not be a significant driver of dissatisfaction with leisure time, especially considering women's on average lesser time spent commuting. It is the combination of the commute alongside tasks associated with childcare, the school run, and the household (e.g. shopping) which reduces satisfaction with the availability of leisure time. This suggestion is consistent with the findings regarding method of transport to work.

Women travelling by car report relatively higher levels of satisfaction with job than those using public transport, reflecting that journeys made using public transport are often multipart, complex, time-consuming and may be (perceived) less reliable or secure (Eriksson et al, 2013). However, the interaction of travel by car (or van/motorbike) and number of dependent children provides important further evidence reflecting the impact of childcare on the use of leisure time. This association is negative for both men and women suggesting that while those without children may benefit from the relative freedom of access to a car, the multi-use nature of travel by car where children are present constrains the use of leisure time due to the temporal and spatial fixity of these activities (Schwanen et al, 2008, 2119). This provides evidence in support of men performing the chauffeuring of children (Schwanen, 2007). Consistent with this it is found that among men the combined impact of the commute and presence of dependent children for those with mid-length commutes is negatively associated with use of leisure time, perhaps reflecting regular chauffeuring activities. However, the predominance of women acting as primary childcarer, evident in the analysis, would suggest the negative impact present on satisfaction with leisure time will be more pronounced for women. This effectively constrains women's time-use, resulting in lower levels of subjective well-being and the persistence of temporal and spatial constraint. 


\section{Conclusion}

This article has investigated the interaction between travel-to-work, time-use, and subjective well-being among UK dual career households, extending previous research into travel-towork among these households (Wheatley, 2012) and the subjective well-being effects of travel-to-work (De Vos et al, 2013; Ettema, 2010, 2012; Roberts et al, 2011; Stutzer and Frey, 2008). The evidence extracted from the BHPS is indicative of a number of consistencies among men and women in highly skilled occupations. For example, overall time-use is relatively comparable between career men and women, although importantly the distribution is distinct. With the exception of some managerial households, the commutes of men and women in dual career households in which both partners work full-time remained distinct throughout the BHPS sample period. Public sector professionals, and associate professionals, report the shortest travel-to-work times. This is of particular interest in the case of professionals as these women work long hours (inclusive of overtime) and report lengthy housework but some of the shortest commutes. This suggests a trade-off among these women as they attempt to manage paid work alongside housework and care, constraining the time available for travel and effectively limiting their spatial mobility. The analysis identifies the implications of the shorter commutes and greater household and caring contribution of women.

Car dependency among career women, most evident among public sector professionals, continues to raise policy concerns. These women use the car for their journey to work, but this may not simply reflect a choice made for convenience (Anable and Gatersleben, 2005), but that these women are undertaking multi-activity journeys (Wheatley, 2012; 2013). This is evident in the results of the regression analysis, while commuting by car is also a concern for men with dependent children. In the UK, a range of targeted policy has been implemented in 
recent years with a focus on reducing car dependency (see HM Treasury, 2006; DfT, 2006, 2007). Targeted policy of this nature, however, may create further complexity for those who remain highly car reliant, and could exacerbate challenges associated with combining household responsibilities and travel-to-work, for example in obtaining workplace car parking (Wheatley, 2012).

The analysis identifies that household factors and travel-to-work routines act as important drivers of satisfaction for women, extending the work of Roberts et al (2011). The impact of the household in reducing satisfaction corresponds with previous research, including Garcia et al (2007). Long commutes (over 60 minutes) are associated with dissatisfaction among men corresponding with the extant literature. Meanwhile, evidence is also indicative of negative subjective well-being effects of travel-to-work for men with dependent children. This is consistent with impacts on leisure time for men performing the chauffeuring of children (Schwanen, 2007). Women's relationship with the commute appears more complex, and is likely driven by their greater household contribution leaking into travel-to-work, creating multi-activity journeys which include childcare activities such as the 'school run'. This has specific impacts on availability of leisure time, but for women this finding is not as evident for use of leisure time. This suggests women may consider childcare and similar activities as distinct from 'leisure'. They reduce the amount of leisure available, but do not appear to impact directly the use of the leisure time that is experienced. Commutes for mothers have particularly negative impacts on satisfaction with leisure. However, this finding is not present for men or women in the most recent time-period considered following the implementation of the Flexible Working Regulations. This may be evident of partners benefiting from greater flexibility in their routines, reducing the constraining effects of dependent children on travel-to-work behaviours and leisure time. Further research is 
undoubtedly required to further unravel the identified relationships between travel-to-work and subjective well-being. Overall, though, the evidence presented is indicative of gendered imbalance in the household division of labour among dual career households. This limits women's spatial and temporal flexibility and acts as a source of dissatisfaction, particularly with availability of leisure time. Changes to social attitudes and the dissolution of gender norms are required to redress the uneven division of household labour and childcare responsibilities which remain present, even among full-time career couples.

\section{References}

Anable, J. Gatersleben, B. (2005). All Work and No Play? The role of Instrumental and Affective Factors in Work and Leisure Journeys by different Travel Modes. Transportation Research Part A, 39(2-3), 163-181.

Andrews, F.M., Withey, S.B. (1976). Social indicators of well-being: Americans’ perceptions of life quality. Plenum, New York.

Basmajian, C. (2010). “Turn on the Radio, Bust out a Song”: the Experience of Driving to Work. Transportation, 37(1), 59-84.

BIS. (2011). Working Time Regulations: Statutory Instruments [online]. Available at: http://www.bis.gov.uk/

Blanchflower, D.G., Oswald. A.J. (2008). Is well-being U-shaped over the life cycle? Social Science \& Medicine, 66, 1733-49.

British Household Panel Survey [computer file], ESRC Research Centre on Micro-social Change. -Colchester: The Data Archive [distributor], 2009. Data files and associated documentation.

Brown, A., Charlwood, A., Spencer, D. (2012). Not all that it might seem: why job satisfaction is worth studying despite it being a poor summary measure of job quality. Work Employment \& Society, 26, 1007-1018.

Carter, P. Butler, D. (2008). Women’s Work: The Workplace and the Spaces Between. The Industrial Geographer, 5(2), 3-18.

Deakin, S., Morris, G. (2012). Labour Law, $6^{\text {th }}$ Edition, Oxford, Hart. 
Delbosc, A., Currie, G. (2011). Exploring the relative influences of transport disadvantage and social exclusion on well-being. Transport Policy, 18 (4), 555-562.

Department for Transport (DfT) (2006). Eddington Transport Study. Available at: www.dft.gov.uk/about/strategy/transportstrategy/eddingtonstudy.

Department for Transport (DfT) (2007). Towards a Sustainable Transport System. Available at: www.dft.gov.uk/about/strategy/transportstrategy/pdfsustaintranssystem.pdf.

De Vos, J., Schwanen, T., Van Acker, V., Witlox, F. (2013).Travel and subjective well-being: a focus on findings, methods and future research needs. Transport Reviews, 33(4), 421-442.

Diener, E., Suh, E. M., Lucas, R. E., Smith, H. L. (1999). Subjective well-being: Three decades of progress. Psychological Review, 125, 276-302.

Dobbs, L. (2007). Stuck in the Slow Lane: Reconceptualizing the Links between Gender, Transport and Employment. Gender, Work and Organization, March, 14(2), 85-108.

Dolan, P., Peasgood, T., White, M. (2008). Do We Really Know What Makes Us Happy? A Review Of The Economic Literature On The Factors Associated With Subjective Wellbeing. Journal of Economic Psychology, 29(1), 94-122.

Eriksson, L., Friman, M., Gärling, T. (2013). Perceived Attributes of Bus and Car Mediating Satisfaction with the Work Commute. Transportation Research Part A: Policy and Practice, 47, 87-96.

Ettema, D., Gärling, T., Olsson, L.E., Friman, M. (2010). Out-of-home activities, Daily Travel, and Subjective Well-Being. Transportation Research Part A, 44, 723-732.

Ettema, D., Friman, M., Gärling, T., Olsson, L.E., Fujii, S. (2012). How in-vehicle activities affect Work Commuters’ Satisfaction with Public Transport. Journal of Transport Geography, 24, 215-222.

Frändberg, L., Vilhelmson, B. (2011). More or less travel: personal mobility trends in the Swedish population focusing gender and cohort. Journal of Transport Geography, 19(6), 1235-1244.

Frey, B. S., Stutzer, A. (2002). Happiness and economics. Princeton: University Press.

Garcia, I., Molina, A., Navarro, M. (2007). How Satisfied are Spouses with their Leisure Time? Evidence from Europe. Journal of Family and Economic Issues, 28, 546-565. 
Green, A. E. (2004). Is Relocation Redundant? Observations on the Changing Nature and Impacts of Employment-related Geographical Mobility in the UK. Regional Studies, 38(6), August, 629-641.

Green, A. E. Owen, D. W. (2006). The Geography of Poor Skills and Access to Work. York: Joseph Rowntree Foundation.

Guillaume, C. Pochic, S. (2009). What Would You Sacrifice? Access to Top Management and the Work-life Balance. Gender, Work and Organization, January, 16(1), 14-36.

Hanson, S. Pratt, G. (1995). Gender, Work and Space. New York: Routledge.

Hardill, I. (2002). Gender, Migration and the Dual Career Household. International Studies of Women and Place series. London: Routledge.

Hjorthol, R., Vågane, L. (2014). Allocation of tasks, arrangement of working hours and commuting in different Norwegian households. Journal of Transport Geography, 35(1), 75-83.

H.M. Treasury (2006). Stern Review on the Economics of Climate Change. Available at: www.hmtreasury.gov.uk/independent_reviews/stern_review_economics_climate_change/stern_review_report.cf m.

Jorgensen, B., Jamieson, R., Martin, F. (2010). Income, sense of community and subjective well-being: Combining economic and psychological variables. Journal of Economic Psychology, 31(4), 612-623.

Kahneman, D. Krueger, A.B., Schkade, D., Schwartz, N., Stone, A. (2004). Toward National Well-being Accounts. The American Economic Review, 94, 429-434.

Kloosterman, R.C. Musterd, S. (2001). The Polycentric Urban Region: Towards a Research Agenda. Urban Studies, 38(4), 623-33.

Lyons, G., Urry, J. (2005). Travel Time Use in the Information Age. Transportation Research Part A, 39(2-3), 257-276.

McDowell, L., Perrons, D., Fagan, C., Ray, K., Ward, K. (2005). The Contradictions and Intersections of Class and Gender in a Global City: placing Working Women's Lives on the Research Agenda. Environment \& Planning A, 37(3), 441-61.

de Meester, E., van Ham, M., (2009). Symmetry and asymmetry in working and commuting arrangements between partners in the Netherlands: does the residential context matter? Environment and Planning A, 41(9), 2181-2200. 
Moktharian, P., Salomon, I. (2001). How derived is the demand for travel? Some conceptual and measurement considerations. Transportation Research Part A, 35(8), 695-719.

Philp, B. Wheatley, D. (2011). Time Scarcity and the Dual Career Household: Competing Perspectives. American Journal of Economics and Sociology, 70(3), 587-614.

Redmond, L., Mokhtarian, P. (2001). The Positive Utility of the Commute: Modeling Ideal Commute Time and Relative Desired Commute Amount. Transportation, 28(2), 179 - 205.

Roberts, J., Hodgson, R., Dolan, P. (2011). "It's driving her mad”: Gender differences in the effects of commuting on psychological health. Journal of Health Economics, 30(5), 1064-76.

Sandow, E. Westin, K. (2010). The Persevering Commuter - Duration of Long-Distance Commuting. Transportation Research Part A, 44(6), 433-445.

Scheiner, J. Holz-Rau, C. (2012). Gendered Travel Mode Choice: a Focus on Car Deficient Households. Journal of Transport Geography, 24, 250-261.

Schwanen, T. (2007). Gender differences in Chauffeuring Children among Dual-Earner Families. The Professional Geographer, 59(4), 447-462.

Schwanen, T., Kwan, M.P., Ren, F. (2008). How fixed is fixed? Gendered rigidity of space-time constraints and geographies of everyday activities. Geoforum, 39(6), 2109-2121.

Sirianni, C., Negrey, C. (2000). Working Time as Gendered Time. Feminist Economics, 6, 59-76.

Stutzer, A., Frey, B. S. (2008). Stress that doesn't Pay: The Commuting Paradox. Scandinavian Journal of Economics, 110(2), 339-366.

Sullivan, O. (2010). Changing Differences by Educational Attainment in Fathers' Domestic Labour and Child Care. Sociology, 44(4), 716-733.

Wheatley, D. (2012). Work-life Balance, Travel-to-Work, and the Dual Career Household. Personnel Review, 41(6), 813-831.

Wheatley, D. (2013). Location, Vocation, Location? Spatial Entrapment among Women in Dual Career Households. Gender, Work and Organization, 20(6), 720-36. 